\title{
Cleaning Up on the Inside: AdDiction, Recidivism, and Substance Abuse Treatment Programs in INDIANA's CORRECTIONAL FACILITIES
}

\author{
Nick J. Erickson*
}

\section{TABLE OF CONTENTS}

I. INTRODUCTION

A. The Issue: Substance Abuse, Addiction, and Recidivism in Indiana's Correctional Facilities ....84

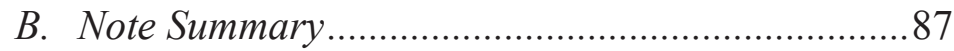

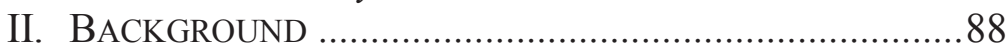

A. In-House Substance Abuse Treatment Programs ..88

B. The Inmate Housing Amendments:

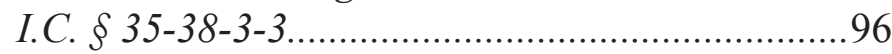

III. ANALYSIS

A. The 2014/2015 Amendments and County Jails: A

Looming Problem.

B. Stiffer Penalties: An Impediment to Progress ......102

C. The Governor's Task Force on Substance Abuse,

Treatment, and Prevention.

D. A Right To Treatment: Cohn v. Strawhorn

1. Section 11-10-3-2: A Statutory Right to Substance Abuse Treatment as "Mental Health Care"

2. Article 1 Section 23: A Right to Substance Abuse Treatment Programs Under the Indiana Constitution's Privileges and Immunities Clause

IV. CONCLUSIONS.

* J.D. Candidate, 2017, Indiana University Robert H. McKinney School of Law, B.A., 2014, Indiana University - Bloomington. 


\section{INTRODUCTION}

\section{A. The Issue: Substance Abuse, Addiction, and Recidivism in Indiana's Correctional Facilities}

David Ward's life began to crumble in the summer of 2013. ${ }^{1}$ He had a wife. ${ }^{2}$ He had a modest but stable job managing a pizza joint in Carmel. ${ }^{3} \mathrm{He}$ and his wife were shopping for a home and were even discussing having a child .${ }^{4}$ Yet, that summer, David found himself in county jail, with divorce papers in his lap and a ten year sentence hanging over his head. ${ }^{5}$ David had become addicted to heroin. ${ }^{6}$ According to David, when he tried heroin, he fully intended it to be his only time using the drug, "a one-time deal." In a short time, David was injecting greater quantities of heroin every day and had pawned off his and his wife's possessions to feed an escalating addiction. ${ }^{8}$ When that revenue stream ran dry, David began breaking into homes for things he could turn into cash for heroin. ${ }^{9}$ After linking several burglarized items in pawn shops to David, the police arrested him. ${ }^{10} \mathrm{He}$ was convicted and is currently serving his sentence at Putnamville Correctional Facility, a state prison

\footnotetext{
${ }^{1}$ Matthew Tully, From Carmel High, to Heroin, to Prison, THE INDIANAPOLIS STAR (Feb. 27, 2015, 9:01 AM), http://www.indystar.com/story/opinion/columnists/matthewtully/2015/02/25/tully-carmel-high-heroin-prison/23997019/ [https://perma.cc/2UU5-SE9Q].
${ }^{2} I d$.
${ }^{3} I d$.
${ }^{4} I d$.
${ }^{5} I d$.
${ }^{6} I d$.
${ }^{7} I d$.
${ }^{8} I d$.
${ }^{9} \mathrm{Id}$.

${ }^{10} I d$.
} 
run by the Indiana Department of Correction ("DOC"). ${ }^{11}$ David Ward is among the $24.4 \%$ of male offenders in state correctional facilities who are serving a sentence for a drugrelated offense. ${ }^{12}$ The reported number is even higher for women, at $37.5 \% .^{13}$

In reality, these percentages may be higher for both men and women. The DOC's 2013 Annual Report suggests that when an inmate is admitted to a correctional facility for multiple offenses, his or her "[o]ffense [c]ategory" for reporting purposes is keyed to that inmate's most serious offense. ${ }^{14}$ This practice is significant because the "Controlled Substance" offense category does not account for all inmates serving time for a drug offense. For example, an inmate serving time for two convictions, armed robbery and drug possession, may be grouped into the "Weapon" or "Person" offense categories, which would be keyed to the robbery offense and not the drug offense. ${ }^{15}$ The offense would be keyed in this way because armed robbery is typically a higher grade criminal offense than drug possession in Indiana. ${ }^{16}$ Likewise, an inmate admitted to a correctional facility for both aggravated battery and possession of drug paraphernalia would be grouped into a category which reflects the battery offense ("Person"), and not the paraphernalia offense because aggravated battery is

\footnotetext{
${ }^{11} I d$.

12 IND. DEP'T OF CORR., 2013 ANNUAL REPORT 79 (2013), http://www.in.gov/idoc/files/2013.DOCAnRep.Final.pdf

[https://perma.cc/LY54-KW3R].

${ }^{13} I d$.

${ }^{14}$ See id. at 80, 83.

${ }^{15}$ See id.

16 See Ind. CoDE ANN. § 35-42-5-1 (West 2014) (classifying a robbery committed while armed with a deadly weapon as a Level 3 felony); IND. CODE ANN. § 35-48-4-6.1(c)(1) (West 2014) (classifying the possession of more than 10 grams but less than 28 grams of methamphetamine as a Level 4 felony).
} 
a more serious offense than possession of paraphernalia in Indiana. ${ }^{17}$ According to the DOC, "[m]any offenders who are sentenced to the DOC system have severe addictions that are directly related to their criminal behavior." 18 Thus, the percentage of the general inmate population with drug convictions must necessarily be higher than the $24.4 \%$ rate of "Controlled Substance" offenses noted in the DOC's 2013 Annual Report. ${ }^{19}$ Further, given that there are likely to be inmates who suffer from substance abuse disorders but have not been convicted of any drug related offense requires acknowledgement of an even greater presence of substance abuse and addiction in Indiana's correctional facilities.

Despite these numbers, David Ward has hope. He is participating in a clean-living program offered in the prison, and he seems to be doing well. ${ }^{20}$ He told an interviewer, "I want to prove to everybody else that I can do it, yes, but I want to prove to myself that I can do this." 21 However, according to Hamilton County Judge Stephen Nation, "the odds are not in his favor." 22

The DOC defines recidivism as "a return to incarceration within three years of the offender's date of release. ..."23 The

17 See InD. CoDE ANN. § 35-42-2-1.5 (West 2014) (classifying aggravated battery as a Level 3 felony); IND. CODE ANN. § 35-48-4-8.3 (West 2015) (classifying the knowing or intentional possession of "an instrument, device, or object intended to introduce a controlled substance into the body" as a Class C misdemeanor).

18 Purposeful Incarceration, IND. DEP'T OF CORRECTION, http://www.in.gov/idoc/2798.htm [https://perma.cc/KKP9-BZCL] (last visited Nov. 1, 2015).

${ }^{19}$ See IND. DEP'T OF CORR., supra note 12.

20 Tully, supra note 1.

${ }^{21} I$.

${ }^{22} I d$.

${ }^{23}$ Ind. Dep't of Correction Adult Recidivism Rates, In.GOV (2014), http://www.in.gov/idoc/files/2014_Adult_Recidivism_Summary.pdf [https://perma.cc/6FRF-63XF]. 
DOC's most recent study in 2014 tracked three-year recidivism for inmates who were released in 2011. ${ }^{24}$ The overall adult recidivism rate for offenders released in 2011 was at $37.6 \%$ in $2014 . .^{25}$ Interestingly, the overall recidivism rate for those designated as having a "Controlled Substance" offense was lower, at $31.8 \%$ in $2014 .{ }^{26}$

However, as noted at greater length above, the overall population of inmates with substance abuse disorders and drug offenses is likely to be far greater than the population of inmates designated as "Controlled Substance" offenders. This disparity is because some drug offenders have a more serious offense that prevents them from being categorized as "Controlled Substance" offenders, ${ }^{27}$ and other offenders who were not convicted of any drug offense at all may nonetheless suffer from substance abuse issues. This insufficiency of data highlights the overall prevalence of substance abuse and addiction within Indiana's correctional system, and it illustrates the challenge of accurately detecting and exploring the relationship between addiction and recidivism.

\section{B. Note Summary}

In Section II-A below, this Note outlines the different DOC substance abuse treatment programs currently available to inmates and to what extent they are available. Section II-B lays out some of the correctional reforms enacted by the Indiana General Assembly in 2014 and 2015.

Section III-A examines the impact of these correctional reforms on both Indiana's county correctional facilities and the availability of substance abuse treatment programs within those facilities, while Sections III-B and III-C

\footnotetext{
${ }^{24} \mathrm{Id}$.

${ }^{25} \mathrm{Id}$.

${ }^{26} I d$.

${ }^{27}$ See supra text accompanying notes $14-17$.
} 
evaluate efforts by Governor Mike Pence and several legislators to explore and expand upon effective drug prevention policies.

Finally, Section III-D examines Cohn v. Strawhorn, a prominent Indiana Court of Appeals case that held that Indiana inmates have neither a statutory nor a constitutional right to treatment access in state or county facilities. This Note argues that this holding was incorrect and that inmates with addiction or substance abuse issues do in fact have a statutory and constitutional right to substance abuse treatment programs.

\section{BACKGROUND}

\section{A. In-House Substance Abuse Treatment Programs}

In 1989, the Indiana General Assembly created a Corrections Drug Abuse Fund, which was to be administered by the DOC for purposes of "provid[ing] drug abuse therapy for offenders." 28 The statute reads, in its entirety:

(a) The corrections drug abuse fund is established. The department shall administer the fund. Expenditures from the fund may be made only in accordance with appropriations made by the general assembly.

(b) The department may use money from the fund to provide drug abuse therapy for offenders.

(c) The treasurer of state shall invest the money in the fund not currently needed to meet the obligations of the fund in the same manner as other public funds may be invested.

\footnotetext{
${ }^{28}$ IND. CODE ANN. § 11-8-2-11 (West 1989).
} 
(d) Money in the fund at the end of a fiscal year does not revert to the state general fund. ${ }^{29}$

The DOC currently deploys these funds in the administration of several substance abuse treatment programs for inmates in Indiana's correctional facilities. ${ }^{30}$ According to the DOC, these programs seek to "address the multiple risk factors contributing to the offenders' substance abuse. They target the offenders' motivation to change, ability to maintain abstinence, as well as intrapersonal and interpersonal concerns." 31

Eight state-sponsored programs are offered in Indiana correctional facilities that seek to provide some measure of substance abuse treatment: Alcoholics Anonymous ("AA"), Narcotics Anonymous ("NA"), Crystal Meth Anonymous ("CMA"), Clean Lifestyle is Freedom Forever ("CLIFF"), the Outpatient Substance Abuse Program, Substance Abuse, Therapeutic Communities ("TCs"), and the Purposeful Living Units Serve ("PLUS") program. ${ }^{32}$

Alcoholics Anonymous, Narcotics Anonymous, and Crystal Meth Anonymous consist primarily of group talk therapy in which participants relay their individual stories of addiction and recovery and offer encouragement and advice to one another. ${ }^{33}$ Civilian volunteers who are also in recovery participate in the program alongside the inmate

${ }^{29} I d$.

30 Programs, IND. DEP'T OF CORRECTION, http://www.in.gov/idoc/2799.htm [https://perma.cc/C7FR-L8B7] (last visited Oct. 23, 2015).

31 Substance Abuse Treatment, IND. DEP'T OF CORRECTION, http://www.in.gov/idoc/2949.htm\#SAT [https://perma.cc/V3YS-

HLKK] (last visited Oct. 23, 2015).

32 See Programs, supra note 30.

${ }^{33} I d$. 
participants. ${ }^{34} \mathrm{AA}, \mathrm{NA}$, and CMA programs are available in all Indiana DOC facilities. ${ }^{35}$

Therapeutic Communities programs are "specialized, intensive [programs] designed to treat offenders with severe drug addictions." ${ }^{36}$ Participating inmates go through twelve to fifteen hours per day of intensive cognitive and behavioral therapy geared toward addiction recovery and relapse prevention, building social and relationship skills, and developing specific skill sets for employment and reintegration. ${ }^{37}$ The TC program lasts a minimum of eight months, but some inmates may take as long as a year to complete the curriculum. ${ }^{38}$ TC programs are currently offered at only nine of the DOC's twenty-one facilities. ${ }^{39}$ The TC programs at these nine facilities have a total participant capacity of $1818 .^{40}$ Interestingly, only one of Indiana's six minimum security facilities provides TC programming. ${ }^{41}$

The DOC's website notes that the recidivism rate for graduates of the Therapeutic Communities programs is half that of the general DOC population. ${ }^{42}$ Yet, of the 1321 inmate graduates of TC programs that were released in calendar year 2011, 513 were re-incarcerated by year-end

\footnotetext{
${ }^{34} \mathrm{Id}$.

${ }^{35} \mathrm{Id}$.

${ }^{36} \mathrm{Id}$.

${ }^{37} I d$.

${ }^{38}$ Purposeful Incarceration, supra note 18.

${ }^{39} \mathrm{Id}$. Note that the source provided here does not explicitly state the number of facilities that offer each program. The number provided here was calculated by counting the facilities listed under each treatment program.

${ }^{40} \mathrm{Id}$.

${ }^{41}$ Id.; Adult Facilities, IND. DEP'T OF CORRECTION, http://www.in.gov/idoc/2332.htm [https://perma.cc/CL76-FZ86] (last visited Oct. 23, 2015).

${ }^{42}$ Programs, supra note 30.
} 
2014, according to a 2014 DOC report. ${ }^{43}$ This translates to a three-year recidivism rate for graduates of TC programs released in 2011 of $38.8 \%$, which is actually slightly higher than the overall population's recidivism rate for $2014 .{ }^{44}$

Clean Lifestyle is Freedom Forever is a modified TC program which exclusively treats methamphetamine addiction. ${ }^{45}$ The program is structured in the same way as a traditional TC program, in that inmates participate in twelve to fifteen hours of intensive counseling per day, for a minimum of eight months. ${ }^{46}$ The program seeks to foster development of similar skills as the general TC program, namely those pertaining to relapse prevention, community reintegration, seeking and retaining employment, and relationship building. ${ }^{47}$ Only three facilities provide this program, with a total participant capacity of $456 .{ }^{48}$

The DOC's website claims that graduates of the Clean Lifestyle is Freedom Forever program have a recidivism rate which is half that of the general DOC population. ${ }^{49}$ However, the DOC's own 2014 recidivism study reports that of the 660 inmates who graduated from the CLIFF program and were released in 2011, 311 had returned to incarceration by $2014 .{ }^{50}$ This represents a recidivism rate of $47.12 \%$, nearly $10 \%$ higher than the general population's $37.6 \%$ rate. $^{51}$

${ }^{43}$ IND. DEP'T OF CORR., THERAPEUTIC COMMUNity 2011 ReleASE COHORT RECIDIVISM STUDY (2015).

${ }^{44} I d$.

${ }^{45}$ Programs, supra note 30.

${ }^{46} \mathrm{Id}$.

${ }^{47} I d$.

${ }^{48} I d$.

${ }^{49} \mathrm{Id}$.

${ }^{50}$ IND. DEP'T OF CORRECTION, CLEAN LIVING IS FREEDOM ForeVER 2011 RELEASE COHORT RECIDIVISM STUDY (2015).

${ }^{51}$ INDIANA DEPARTMENT OF CORRECTION, supra note 23. 
The Outpatient Substance Abuse Program is a multiphase program available in all Indiana DOC facilities. ${ }^{52}$ The first, introductory phase consists of a guided self-study which is structured around a basic drug education manual. ${ }^{53}$ The next phase consists of cognitive behavioral counseling which follows both Federal Bureau of Prisons guidelines and Dr. Stanton Samenow's three-part "Commitment to Change" program. ${ }^{54}$ Dr. Samenow's 1994 program is composed of a series of videos with corresponding workbooks. ${ }^{55}$ The final phase of the Outpatient Substance Abuse program comprises of different segments which prioritize reintegration and relapse prevention. ${ }^{56}$ This final phase follows such curricula as the 12 Steps, Texas Christian University's "Straight Ahead" materials, and other resources. ${ }^{57}$

The Purposeful Living Units program, while not an exclusively drug-oriented rehabilitation program, can be catered to the individual circumstances of inmates who face substance abuse issues. ${ }^{58}$ The PLUS units primarily work through a counseling regiment which is rooted in faith-based and character-building frameworks. ${ }^{59}$ While this program is highly individualized in response to each participant's circumstances and challenges, it prioritizes life skill development, community service, and strategies for successful reintegration into society. ${ }^{60}$ According to the

\footnotetext{
${ }^{52}$ Programs, supra note 30.

${ }^{53} \mathrm{Id}$.

${ }_{55}^{54} I d$.

55 Stanton E. Samenow, Ph.D., Psychology TOdAy, https://www.psychologytoday.com/experts/stanton-e-samenow-phd [https://perma.cc/6534-KL8A] (last visited Oct. 23, 2015).

${ }^{56} I d$.

${ }^{57}$ Programs, supra note 30.

${ }^{58} I d$.

${ }^{59} \mathrm{Id}$.

${ }^{60} \mathrm{Id}$.
} 
DOC, the PLUS program is offered in sixteen of its facilities. ${ }^{61}$

The DOC's website claims that the "current [recidivism] rate of PLUS graduates is less than 5\%, compared with the overall recidivism rate of $37 \% .{ }^{\prime \prime 2}$ However, according to the DOC's 2014 evaluation of the PLUS program, by year-end 2014 that recidivism rate (the rate of PLUS program graduates released in calendar year 2011 who returned to incarceration by December 31,2014) was $31.46 \%$, far closer to the overall adult recidivism rate. ${ }^{63}$ In other words, of the 410 graduates of the PLUS program who were released during 2011, 129 had returned to incarceration by $2014 .{ }^{64}$

The Substance Abuse program is an individualized program in which inmate participants receive limited, cursory services such as assessments, educational materials, and referrals for treatment. ${ }^{65}$ Substance Abuse is a relatively informal program relative to the other DOC programs, in that its primary mission is merely to "provide effective substance abuse treatment in all [Indiana DOC] facilities" by evaluating each individual offender's needs "within the constraints of available resources." ${ }^{\prime 66}$ Thus, the purpose of the Substance Abuse program is to direct inmates to the more in-depth programs available in their respective facilities.

In order to participate in one of the DOC's substance abuse treatment programs, inmates must submit a request form and meet a number of eligibility criteria. ${ }^{67}$ Namely, an inmate must 1) have a documented significant history of

${ }^{61} I d$.

${ }^{62} \mathrm{Id}$.

63 Ind. DeP'T of Correction, Purposeful Living Units SERVE (PLUS) 2011 RELEASE COHORT RECIDIVISM STUdy (2015).

${ }^{64} \mathrm{Id}$.

${ }^{65}$ Programs, supra note 30.

${ }^{66} \mathrm{Id}$.

${ }^{67} \mathrm{Id}$. 
substance abuse; 2) be willing to sign and conform to a behavioral contract, as well as an agreement to complete all program homework assignments; and 3) agree to be subject to urine screenings at any time. ${ }^{68}$

Given the limited resources and capacity of these treatment programs, admission is limited on the basis of an inmate's earliest possible release date. ${ }^{69}$ In addition, in order to be eligible, inmates must also have enough time to fully complete a given treatment program from their date of admission to the program and their earliest possible release date. ${ }^{70}$ Further, otherwise eligible inmates who demonstrate a desire to participate in a treatment program only for purposes of obtaining a modified sentence (i.e. inmates who do not demonstrate a concurrent, good faith desire to develop skills for relapse prevention, community reintegration, etc.) may be rejected from participation in a program. ${ }^{71}$

The Indiana DOC's Purposeful Incarceration initiative seeks to foster collaboration between the DOC and the judges of Indiana's courts to ensure inmates with substance abuse disorders are fed into facilities where they may access the proper treatment programs for their needs. ${ }^{72}$ At the sentencing phase, judges will document their willingness to "consider a sentence modification" for chemically addicted inmates who participate in one of the DOC's Therapeutic Community programs. ${ }^{73}$ The Purposeful Incarceration initiative provides judges with the opportunity to further collaborate with the DOC at the outset, in seeking to place inmates in facilities that provide the proper Therapeutic

\footnotetext{
${ }^{68} I d$.

${ }^{69} \mathrm{Id}$.

${ }^{70} \mathrm{Id}$.

${ }^{71}$ Id.

${ }^{72}$ Purposeful Incarceration, supra note 18.

${ }^{73} I d$.
} 
Community program. ${ }^{74}$ For example, if an inmate has a substance abuse issue with methamphetamine in particular, that inmate will be placed in a facility which administers the CLIFF program. ${ }^{75}$ Upon his or her arrival at the facility, the inmate will be evaluated by the facility's Substance Abuse staff to assess that inmate's eligibility for particular programs. ${ }^{76}$ If the inmate becomes enrolled in a program, the sentencing court will be notified of his or her participation, and will receive periodic updates on that inmate's progress. ${ }^{77}$ An officer of the court may also visit the inmate to evaluate that inmate's progress in person. ${ }^{78}$ On the other hand, if the inmate refuses to participate in a treatment program, the court will be notified of that refusal. ${ }^{79}$ In addition to state correctional facilities, there are seventeen county facilities participating in the Purposeful Incarceration initiative. ${ }^{80}$

The reader should note while evaluating some of the recidivism rates of these programs alongside that of the general population, the inmates who have participated and graduated from these programs have been designated by the DOC as having a level at or greater than three on the Texas Christian University Drug Screen, indicating that the individual has some manner of substance abuse disorder. ${ }^{81}$ Therefore, the recidivism rates for those DOC inmates

${ }^{74} \mathrm{Id}$.

${ }^{75} \mathrm{Id}$.

${ }^{76} \mathrm{Id}$.

${ }^{77} I d$.

${ }^{78} I d$.

${ }^{79} I d$.

${ }^{80} \mathrm{Id}$.

${ }^{81}$ Email from Sarah Schelle, Research Analyst, Indiana Department of Correction, to Nick J. Erickson, J.D. candidate, Indiana University Robert H. McKinney School of Law (Oct. 21, 2015, 01:06 PM EST) (on file with author); see TEX. Christian UnIV., TCUDS V - TCU DRUG SCREEN V, SCORING \& INTERPRETATION GUIDE (2014) http://ibr.tcu.edu/wp-content/uploads/2014/11/TCUDS-V-sgv.Sept14.pdf [https://perma.cc/Q5QF-DRS3]. 
participating in treatment programs are not directly comparable to the recidivism rates for the general prison population or even for inmates serving time for simple drug possession or paraphernalia offenses. Failing any direct comparability, the heightened recidivism rates for graduates of these substance abuse programs demonstrate the clear role substance abuse plays in driving recidivism and highlight the need for further exploration into the efficacy and availability of treatment programming.

B. The Inmate Housing Amendments: I.C. § 35-38-3-3

On March 26, 2014, the General Assembly passed and the Governor signed Public Law 168. ${ }^{82}$ The law amended section 35-38-3-3 of the Indiana Code by broadening a 1989 law which prohibited misdemeanor offenders from being housed in state DOC facilities; the 2014 amendment added Level 6 Felony offenders to that category of inmates who may not be housed in state facilities under certain circumstances. ${ }^{83}$ The amendment reads, in relevant part:

(c) After June 30, 2014 and before July 1, 2015, a court may not commit a person who commits a Level 6 Felony to the department of correction [i.e. a state facility] if the person's earliest possible release date is less than ninety-one (91) days from the date of sentencing, unless the commitment is due to the person violating a condition of probation, parole, or community corrections by committing a new criminal offense.

822014 Ind. Legis. Serv. P.L. No. 168-2014, sec. 62 (H.E.A. 1006)

(West) (codified as amended at IND. CODE $\S 35-38-3-3(c)$, (d) (2014)) https://iga.in.gov/legislative/2014/bills/house/1006\#

[https://perma.cc/SN6T-854B].

${ }^{83} \mathrm{Id}$. 
(d) After June 30, 2015, a court may not commit a person convicted of a Level 6 Felony to the department of correction if the person's earliest possible release date is less than . . . (366) days from the date of sentencing, unless the commitment is due to the person violating a condition of probation, parole, or community corrections by committing a new criminal offense. ${ }^{84}$

In May 2015, the Indiana General Assembly passed and the Governor signed Public Law 179, which further broadens the amendment introduced under the 2014 law. ${ }^{85}$ Most notably, the 2015 amendment extends the end of the period in subsection (c) from July 1, 2015 to January 1, 2016, thus including more Level 6 Felony offenders into the statute's coverage. ${ }^{86}$ Additionally, subsection (d) was amended such that the period beginning June 30, 2015 would begin instead on December 31, 2015. ${ }^{87}$ The amendment also omits the limiting requirement from subsection (b) that an inmate's earliest possible release date be fewer than 366 days from the date of sentencing, and adds new language, so that subsection (d) now reads, in relevant part:

(d) After December 31, 2015, a court may not commit a person convicted of a Level 6 Felony to the department of correction unless:

${ }^{84} I d$. (emphasis added).

${ }^{85} 2015$ Ind. Legis. Serv. P.L. No. 179-2015, sec. 17 (West) (codified as amended at IND. CODE $\S$ 35-38-3-3(c), (d) (2015)) https://iga.in.gov/legislative/2015/bills/house/1006\#document21b8684f [https://perma.cc/HF6L-XLV6].

\footnotetext{
${ }^{86} \mathrm{Id}$.
}

${ }^{87} \mathrm{Id}$. 
(1) the commitment is due to the person violating a condition of probation, parole, or community corrections by committing a new criminal offense; or

(2) the person is convicted of

(A) at least two (2) Level 6 felonies that are ordered to be served consecutively; or (B) a Level 6 felony that is enhanced by an additional fixed term ....; and the person's earliest possible release date is more than three hundred sixty-five (365) days after the date of sentencing. ${ }^{88}$

Thus, the 2015 amendment lengthens the period during which certain Level 6 Felony offenders will be routed to county facilities, but also creates new exceptions under which Level 6 inmates may still be housed in state facilities. ${ }^{89}$ It remains, however, that all first-time offenders with one Level 6 Felony conviction who were convicted between June 30, 2015 and January 1, 2016 will be passed on to county facilities if sentenced to incarceration. ${ }^{90}$

I will now turn to the impact of these amendments with respect to the availability of substance abuse treatment programs in county facilities.

\footnotetext{
${ }^{88} \mathrm{Id}$. (emphasis added).

${ }^{89} \mathrm{Id}$.

${ }^{90} \mathrm{Id}$.
} 
III. ANALYSIS

\section{A. The 2014/2015 Amendments and County Jails: A Looming Problem}

One study cited by the Indianapolis Star estimated that the class of Level 6 Felony offenders incorporated by the 2014 amendment alone constitutes roughly 14,000 individual inmates. ${ }^{91}$ The principal reason for the amendment was to ease the overcrowding in state DOC facilities. ${ }^{92}$ However, many of these offenders will instead be housed in county facilities, which are themselves struggling with capacity and overcrowding. ${ }^{93}$ Thus, predictably, county jail administrators are concerned with the redirection of Level 6 Felony offenders from state DOC facilities to county jails.

The inmate population at Allen County's jail, for instance, is at $96 \%$ capacity. ${ }^{94}$ Allen County Commissioner Therese Brown has expressed concern that this influx of offenders into county facilities may "dramatically affect the county's finances," despite the Indiana General Assembly's authorization of grant funding for the county facilities that

91 Kristine Guerra, County Jails Fear Onslaught of Addicts, Mentally Ill from Prisons, THE IndianAPOLIS STAR (Feb. 2, 2015, 9:44 AM), http://www.indystar.com/story/news/politics/2015/02/02/countyjails-ready-onslaught-addicts-mentally-prisons/22698401/ [https://perma.cc/B8GM-HKXM].

92 Jack Rinehart, Indiana Prisons to No Longer Accept D-Felons Due to Overcrowding, INDY CHANNEL, http://www.theindychannel.com/news/local-news/indiana-prisons-tono-longer-accept-d-felons [https://perma.cc/TV6Z-MKWX] (last updated Apr. 15, 2014, 7:31 PM).

93 Dave Gong, County Seeks State Funds for Jail, J. GAZETTE (Dec. 14, 2014, 1:03 AM), http://www.journalgazette.net/news/local/Countyseeks-state-funds-for-jail-3932261, [https://perma.cc/9TPB-DH5C].

${ }^{94}$ Id. 
house state DOC inmates..$^{95}$ In addition, Allen County is struggling to offer treatment programming for its current population; Allen County is already at capacity for these programs. ${ }^{96}$ Along with its substance abuse treatment, the county's work release and community correction programs are also at capacity, despite there being many inmates who otherwise qualify for participation. ${ }^{97}$ According to the Allen County Director of Government Affairs, Beth Lock, the county is evaluating the feasibility of purchasing additional facilities to expand work release program availability. ${ }^{98}$

However, it is not apparent whether Allen County is exploring any opportunities for expanding access to substance abuse treatment programs, in particular. In terms of expanding sheer physical capacity, a more immediate operational concern, Lock estimates that adding a mere 7080 beds would cost the county roughly one million dollars. ${ }^{99}$ This figure does not include the additional personnel costs, the daily cost of housing each new inmate, etc. ${ }^{100}$ Thus, the county is struggling to properly balance the financial burdens introduced by the reorganization of inmate housing under the 2014 amendment.

Allen County is not the only county that is concerned. Johnson County's jail, for instance, is also near capacity. ${ }^{101}$ Marion County Sherriff John Layton has also said, "[The 2014 amendment is] going to cause a spider web of problems for those [county] facilities [that] take offenders back from the state and for us to retain the others when they should go

\footnotetext{
${ }^{95} \mathrm{Id}$.

${ }^{96} \mathrm{Id}$.

${ }^{97} \mathrm{Id}$.

${ }^{98} \mathrm{Id}$.

${ }^{99} \mathrm{Id}$.

${ }^{100} \mathrm{Id}$.

${ }^{101}$ Rinehart, supra note 92.
} 
to the [state DOC facilities]."102 The Indiana Sherriff's Association has also expressed concern that county jails may become a "dumping ground" for offenders who should otherwise be housed in state facilities. ${ }^{103}$ Franklin County Sherriff Ken Murphy has expressed particular concern over the influx of inmates with serious mental illnesses and addictions. ${ }^{104}$ Murphy points out that, of the inmates who need mental health or substance abuse treatment, many require medication which can cost hundreds of dollars a month. ${ }^{105}$

Another county which prompts particular concern is Scott County, where a surge in intravenous drug (predominantly heroin) use has prompted an HIV epidemic. ${ }^{106}$ The problem has reached such a height as to prompt Governor Pence to declare a public health emergency in Scott County. ${ }^{107}$ While Scott County's jail is currently undergoing an $\$ 11.5$ million expansion in order to increase is housing capacity, the expansion is financed entirely by the county itself. ${ }^{108}$ Thus, the prospect of the county being able to subsequently finance a concurrent expansion of substance abuse treatment programs to keep pace with the increase in population is dubious.

102 Id.

${ }^{103} I d$.

104 Guerra, supra note 91.

${ }^{105} \mathrm{Id}$.

106 Shari Rudavsky, Needle Exchange in Scott County Off to Slow Start, THE IndianAPOLIS STAR (Apr. 7, 2015, 6:33 PM), http://www.indystar.com/story/news/2015/04/07/needle-exchangescott-county-slow-start/25410915/ [http://perma.cc/P7Z9-PJT9].

107 Id.

${ }^{108}$ Emily Mieure, Multi-Million Dollar Scott Co. Jail Expansion Underway, WDRB.com (Feb. 4, 2015, 6:12 PM), http:/www.wdrb.com/story/28026111/multi-million-dollar-scott-cojail-expansion-underway [http://perma.cc/Z2H8-BTMF]. 
Although the 2014 law authorizes an additional $\$ 80$ million in funding over two years for the express purpose of improving and expanding substance abuse treatment in county jails, many fear it will not be enough. ${ }^{109}$ For instance, Larry Landis, Executive Director of the Indiana Public Defender Council, has said there is a general consensus among Indiana legislators that the $\$ 80$ million authorized by the General Assembly thus far is not sufficient to sustain the reforms under the 2014 amendment. ${ }^{110}$ Sherriff Murphy echoed this sentiment, arguing that the benefits of the 2014 amendment could be compromised entirely without additional funding. ${ }^{111}$ Further, by extending the period of Level 6 Felony inmate redirection by six additional months, the 2015 amendment has magnified the pressure placed on counties.

\section{B. Stiffer Penalties: An Impediment to Progress}

Some state policymakers, like State Senator Jim Merritt of Indianapolis and David Powell, the Executive Director of the Indiana Prosecuting Attorneys Council, argue that alongside this increase in treatment must be a corresponding increase in the severity of penalties for drug-related offenses. ${ }^{112}$ Governor Pence has also advocated for "very aggressive" enforcement of the state's drug laws. ${ }^{113}$ One rationale behind this proposal is that the prospect of longer

${ }^{109}$ Guerra, supra note 91.

${ }^{110} I d$.

111 Id.

112 Chelsea Schneider \& Jill Disis, Pence Task Force to Combat Drug Abuse "Scourge”, THE InDIANAPOLIS STAR (Sept. 2, 2015 7:46

AM), http://www.indystar.com/story/news/politics/2015/09/01/govpence-roll-anti-drug-plan-discuss-crime/71503006/

[http://perma.cc/DK6D-GB8Z].

${ }^{113} I d$. 
sentences and tougher penalties may help prosecutors and courts to persuade drug offenders to seek treatment. ${ }^{114}$ Another traditional argument in favor of tougher criminal penalties for drug offenses is that such penalties may serve either as a stronger deterrent for drug offenders to continue violating the law or as a general deterrent for people who have not yet violated the law. ${ }^{115}$

The notion of stiffening penalties for drug crimes as a deterrent sounds attractive at first glance. Yet, addiction and substance abuse disorders do not operate under the same logic of self-preservation as other decision-making processes. Take, for instance, the story of David Ward recounted above. David sold all of his and his wife's possessions, lost his job, and began breaking into other peoples' homes, all to placate his insatiable need for a fix of heroin. ${ }^{116}$ The prospect of criminal liability played little to no role in David's decision-making process once his use of heroin rose from the level of recreational use to a compulsive addiction. The breakdown in rational thought David suffered is by no means an anomaly for individuals with substance abuse disorders. According to Dr. Timothy J. Kelly, an addiction specialist at Clearvista Recovery Associates:

The repeated use of a psychoactive/addictive drug in vulnerable individuals, can result in

\footnotetext{
${ }^{114} \mathrm{Id}$.

115 See, e.g. Steven Nauman, Brown v. Plata: Renewing the Call to End Mandatory Minimum Sentencing, 65 FLA. L. REV. 855, 861 (2013) ("[Proponents of mandatory minimum sentences] pointed to the overall inability to deter future crime as indeterminate sentencing's pervading deficiency. The idea behind deterrence is that when a person commits a crime, he is sufficiently punished to dissuade him from committing the same crime again - or any other crime for that matter - in the future. As a corollary, the general public also sees the criminal's punishment and is similarly dissuaded from committing that crime.") (citations omitted).

116 Tully, supra note 1.
} 
addiction, which is characterized by an intense desire for that drug combined with an impaired ability to control that urge even in the face of adverse, even catastrophic consequences (e.g. incarceration, loss of child custody, loss of medical licensure, et cetera). ${ }^{117}$

Dr. Deborah McMahan, the Health Commissioner for Allen County, characterized addiction as having "long term economic and social impact and high mortality." 118 Kevin Moore, Director of the Indiana Family and Social Services Administration's Division of Mental Health \& Addiction, has further posited that $80 \%$ of Indiana's prisoners housed in state facilities suffer from addiction, while an estimated $68 \%$ of all county jail inmates suffer from addiction. ${ }^{119}$ This compares to an addiction rate of approximately $8.8 \%$ in the general Indiana population. ${ }^{120}$

Thus, it is clear that there is a positive correlation between generally criminal behavior and substance abuse; much of the anecdotal and medical evidence suggests that such antisocial behavior can stem from the breakdown in cognitive and inhibitory function which accompanies

117 Timothy J. Kelly, GOVERnOR's TASK ForCE ON DRUG ENFORCEMENT TREATMENT AND PREVENTION, ADDICTION 101, 22 (Sept. 16, 2015), http://www.in.gov/gtfdetp/2409.htm [https://perma.cc/QJ3C-L28H] (emphasis added).

118 Deborah McMahan, GOVERnOR's TASK Force ON DRUG EnForcement TREATMEnt AND PREVEntion, The OpioId CRISIS IN ALLEN COUNTY 50 (Nov. 19, 2015), http://www.in.gov/gtfdetp/2409.htm [https://perma.cc/QJ3C-L28H].

119 KeVIN MOORE, GOVERNOR's TASK FORCE ON DRUG ENFORCEMENT TREATMENT AND PREVENTION, RECOVERY WORKS: IndianA's ForEnsiC TREATMENT PROGRAM, 4 (Nov. 19, 2015), http://www.in.gov/gtfdetp/2409.htm [https://perma.cc/QJ3C-L28H].

${ }^{120} I d$. 
substance abuse and addiction. ${ }^{121}$ It thus appears highly unlikely that the prospect of stiffer penalties will play any meaningful role in deterring drug users from continuing to abuse such illicit substances, or in incentivizing them to seek treatment.

Practically speaking, it is true that tougher sentences for drug offenses would bring more individuals who need intervention and treatment into the correctional system, where some substance abuse treatment programs are available. Yet, all else held constant, lengthening sentences for drug offenses would likely divert a greater number of individuals into state and county facilities. This would further strain the availability of substance abuse treatment programs, and would also magnify the financial burden placed on facilities housing such individuals. The new correctional housing scheme under the amendments to section 35-38-3-3 will likely increase the populations of county jails even further by redirecting Level 6 Felony offenders to the counties. This would further amplify the overall operational and financial burdens faced by affected county facilities.

Another argument in favor of stiffer penalties may be that the higher rates of incarceration for drug offenses are not caused by an uptick in both the frequency and intensity of prosecution, but by an overall increase in the use of drugs.

${ }^{121}$ Drugs, Brains, and Behavior: The Science of AdDiction, NAT'L INST. DRUG ABUSE 7 (2014), https://www.drugabuse.gov/publications/drugs-brains-behaviorscience-addiction/drug-abuse-addiction [https://perma.cc/NB2Y$\mathrm{RBCY}$ ] ("Brain imaging studies of people with addiction show physical changes in areas of the brain that are critical to judgment, decision making, learning and memory, and behavior control.") (citing Joanna S. Fowler, Nora D. Volkow, Cheryl A. Kassed \& Linda Chang, Imaging the Addicted Human Brain, 3 SCI. \& PraC. PersP. 4-16 (2007), https://www.ncbi.nlm.nih.gov/pmc/articles/PMC2851068/pdf/spp-032-4.pdf [https://perma.cc/D87N-SSBV]). 
However, it appears that drug use, especially among youth, is in fact decreasing. ${ }^{122}$

It may be true that being "tough" on crime, to an extent, deters some would-be drug users. But given the high rates of recidivism for drug offenders, ${ }^{123}$ it is clear that increasing penalties alone will not break the cycle of addiction, criminal behavior, and incarceration. Beyond its lack of efficacy, this approach would place a greater financial strain on the state and on counties, both of whom are only beginning to address the resurgence of heroin and opioid abuse in Indiana and the resulting HIV outbreak. ${ }^{124}$

Of course, this note does not purport to outline a comprehensive, all-encompassing policy for dealing with these issues of addiction, disease, and criminality. However, pragmatism calls for renewed attention by the legislature regarding how to allocate limited resources toward tackling one corner of the problem. Counties are already struggling to stay afloat, and county administrators fear the recent appropriations are not enough. ${ }^{125}$

At the very least, we should strive to adequately fund substance abuse programming and research in order to reduce recidivism among current inmates. As those inmates are released, overall population in facilities will decrease over time, freeing resources. Critics of this approach may ask: Where can we find the resources needed to implement this recidivism reduction plan? The answer is to do the opposite of "getting tough" on drug offenders. Namely, we need to wind down the pursuit and prosecution of first-time

122 Lloyd D. Johnston et AL., NAT'L Inst. Drug ABUSE, 2015 Overview Key Findings on AdOLESCENT Drug Use 1, 5 (Feb. 2016), http://www.monitoringthefuture.org/pubs/monographs/mtfoverview2015.pdf [https://perma.cc/4MCG-CBVJ].

${ }^{123}$ INDIANA DEPARTMENT OF CORRECTION, supra note 23.

${ }^{124}$ Rudavsky, supra note 106.

125 Gong, supra note 93. 
drug offenders. Ideally, however, repeat offenders would be prosecuted and brought into the system, where they would receive the appropriate treatment. In this way, renewed emphasis on rehabilitation, long considered a touchstone of Indiana's criminal justice system, will serve to ameliorate the pressures faced by overcrowded and underfunded facilities. ${ }^{126}$

\section{The Governor's Task Force on Substance Abuse, Treatment, and Prevention}

In September 2015, Governor Pence convened the Governor's Task Force on Substance Abuse, Treatment, and Prevention. ${ }^{127}$ The task force itself is a multi-disciplinary body of various community stakeholders, including state administrators, legislators, law enforcement, judges, attorneys, and private healthcare providers. ${ }^{128}$ According to Governor Pence, the primary purpose of the task force is to "identify gaps that can hinder us from preventing drug abuse, treating drug abuse, and effectively enforcing our laws." 129 At the time of this writing, the task force has met five times, once monthly between September 2015 and January 2016. ${ }^{130}$

During these meetings, various doctors, law enforcement officers, and other individuals present their findings regarding a particular issue in drug abuse within his or her relevant area of expertise, and make recommendations as to

${ }^{126}$ IND. CONST. art. I, $\S 18$ ("The penal code shall be founded on the principles of reformation, and not of vindictive justice.").

${ }^{127}$ Schneider \& Disis, supra note 112.

128 Members, Drug Enforcement Treatment \& Prevention, http://www.in.gov/gtfdetp/2333.htm [https://perma.cc/MM69-VM8J] (last visited Feb. 13, 2016).

${ }^{129}$ Schnieder \& Disis, supra note 112.

130 Meetings, Drug Enforcement Treatment \& Prevention, http://www.in.gov/gtfdetp/2409.htm [https://perma.cc/QJ3C-L28H] (last visited Mar. 11, 2016). 
solving that particular problem. ${ }^{131}$ After each meeting, Governor Pence has directed various state agencies to act upon the recommendations of the task force to develop new programs and instill best practices into existing programs. ${ }^{132}$ It is also expected that the General Assembly will explore some of the task force's recommendations during its next legislative session. ${ }^{133}$

This multidisciplinary approach is particular effective, in that it brings together varying perspectives and lends a multidimensional perspective to the complex and vexing social problems of addiction and mental health. Such a pragmatic, evidence-based process is sure to yield promising results in terms of programming and sustained cooperation across various industries and professions. Governor Pence's initiative in directing state administrative bodies to implement some of the task force's recommendations further ensures sustained attention and dedication to systemic improvements in the provision of mental health and substance abuse care across Indiana.

However, while this is certainly constructive, the task force ought to place more emphasis on reforms within and ancillary to the correctional system. By examining more closely things such as drug courts, the DOC's substance abuse programs, juvenile diversion programs, and correctional funding issues, the task force can make a greater contribution toward reducing recidivism and minimizing the

\footnotetext{
131 See, e.g., Daniel O'Donnell, Police and Naloxone "The Indianapolis Experience" 23, 23, http://www.in.gov/gtfdetp/files/January_29th_Drug_Task_Force_Powe rPoint.ppsx [https://perma.cc/MQ2V-VMQG].

${ }^{132}$ See Governor Pence Directs Action on Recommendation from Meeting of Governor's Task Force on Drug Enforcement, Treatment, and Prevention, IN.GOV (Feb. 4, 2016), $\mathrm{http}: / / \mathrm{www}$.in.gov/activecalendar/EventList.aspx?view=EventDetails\& eventidn $=242130 \&$ information_id $=237140 \&$ type $=\&$ syndicate $=$ syndica te [https://perma.cc/3YS9-PHQJ].

${ }^{133}$ Schneider \& Disis, supra note 112.
} 
kinds of criminal behavior that are driven in large part by drug abuse and addiction.

\section{A Right To Treatment: Cohn v. Strawhorn}

In light of this discussion regarding substance abuse treatment programs in correctional facilities, it is important to address the prospect of there being a right of access to inhouse substance abuse treatment for addicted prisoners under Indiana law. In 1999, the Indiana Court of Appeals held in Cohn v. Strawhorn that there was no such right. ${ }^{134}$

In Strawhorn, a group of Indiana DOC inmates who were housed in county jails brought a class action against the Commissioner of the DOC. ${ }^{135}$ The inmate plaintiffs alleged, in part, that the failure to provide substance abuse programming in the county jails in which they were housed constituted a violation of their statutory and constitutional rights to such programs. ${ }^{136}$

Specifically, the plaintiffs claimed that section 11-10-32(c) of the Indiana Code granted them the statutory right to substance abuse treatment programs. ${ }^{137}$ That statute read (and currently reads) in the relevant part, "[A] confined person is entitled to ... mental health care by a psychiatrist, a psychologist, or another mental health professional." 138 The inmates' claim hinged upon an interpretation of section 11-10-3-2(c) which included substance abuse treatment within the statutory meaning of the term "mental health care." 139

${ }^{134}$ Cohn v. Strawhorn, 721 N.E.2d 342, 344, 351 (Ind. Ct. App. 1999).

${ }^{135} \mathrm{Id}$. at 344 .

${ }^{136} \mathrm{Id}$. at 346 .

${ }^{137} \mathrm{Id}$. at 348 .

${ }^{138}$ IND. CODE ANN. § 11-10-3-2(c) (West 1979) (emphasis added).

139 Strawhorn, 721 N.E.2d at 346. 
The court declined to adopt this interpretation, and granted summary judgment for the defendants on the statutory claim. ${ }^{140}$ In reaching this decision, the court looked to another statute, section 11-10-8-2(a)(4) of the Indiana Code, which read in relevant part, "The department shall establish a ... program in which eligible committed offenders may be temporarily released from custody to . . . obtain medical, psychiatric, or psychological treatment, including treatment for drug addiction or alcoholism." 141 The court reasoned that because the language of section 1110-3-2(c) did not expressly delineate substance abuse treatment as section 11-10-8-2(a)(4) had, it was therefore evident that the legislature did not intend for the statutory entitlement to "mental health care" in section 11-10-3-2(c) to extend to drug treatment programs. ${ }^{142}$

The plaintiffs also argued, among other things, that the disparity in the provision of substance abuse treatment programs between state and county facilities amounted to a violation of the Privileges and Immunities Clause of the Indiana Constitution. ${ }^{143}$ The Privileges and Immunities Clause can be found in Article I Section 23 of the Indiana Constitution. It reads, "The General Assembly shall not grant to any citizen, or class of citizens, privileges or immunities, which, upon the same terms, shall not equally belong to all citizens." 144

The court rejected the plaintiffs' Article 1 Section 23 claim, reasoning that there were "inherent characteristics" beyond geographic location which distinguished the class of plaintiffs (DOC inmates in county facilities) from DOC inmates in state facilities, and that those differentiating

\footnotetext{
${ }^{140} \mathrm{Id}$. at 348 .

${ }^{141} I d$. (emphasis added).

${ }^{142}$ Id. at 349-50.

${ }^{143} \mathrm{Id}$.

${ }^{144}$ IND. CONST. art. I, § 23.
} 
characteristics prevented the disparity in treatment between the two classes from amounting to constitutional impermissibility. ${ }^{145}$ Among these characteristics, the court relied primarily on the "substantially shorter sentences" served by county inmates on average in comparison to DOC inmates in state facilities. ${ }^{146}$ The court characterized this distinction as rational legislative line-drawing, and not an unconstitutionally deliberate or arbitrary distinction. ${ }^{147}$

Additionally, the court cited the "negative fiscal ramifications" it presumed would result from any ruling which would require the provision of substance abuse treatment programming to all inmates, irrespective of the facility in which they were housed. ${ }^{148}$ To that end, the court merely stated that the high costs it anticipated rendered it "absurd to conclude that the General Assembly could have intended that all DOC inmates be entitled to substance abuse treatment regardless of whether they in fact suffer from substance abuse." 149

Particularly noteworthy is Judge Sullivan's dissent. He argues that a statutory right to substance abuse treatment programs does indeed exist. ${ }^{150}$ His conclusion relies primarily on a rejection of the majority's construction of the language in section 11-10-3-2(c). ${ }^{151} \mathrm{He}$ argues that the language of section 11-10-8-2(a)(4) cited by the majority in fact supports a construction of section 11-10-3-2(c) entirely the opposite of that reached by the majority. ${ }^{152}$ He writes, "[I]t is my interpretation that the phrasing by the legislature

${ }^{145}$ Cohn v. Strawhorn, 721 N.E.2d 342, 351 (Ind. Ct. App. 1999).

${ }^{146} \mathrm{Id}$.

${ }^{147}$ Id. at $348-49$.

${ }^{148} I d$. at 351 .

${ }^{149} \mathrm{Id}$. at 348 .

${ }^{150} \mathrm{Id}$. at 353 .

${ }^{151} \mathrm{Id}$.

${ }^{152} \mathrm{Id}$. 
in section 11-10-8-2(a)(4) constitutes recognition that substance abuse treatment is medical and mental health treatment." ${ }^{153} \mathrm{He}$ continued by reasoning that this clear definition by the General Assembly in section 11-10-82(a)(4) rendered it unnecessary to "state the obvious" that substance abuse treatment is medical or mental health treatment in every subsequent statutory provision relating to medical or mental health care. ${ }^{154}$

Though the Indiana Supreme Court ultimately denied transfer to the petitioner inmates in Strawhorn, there are compelling arguments for the proposition that the statutory holding of the Court of Appeals was in error. Additionally, failing a direct overturn of Strawhorn's constitutional holding, the new inmate housing scheme under the 2014 and 2015 amendments to section 35-38-3-3 warrants a revisiting, on new facts, of the Article 23 issue.

\section{Section 11-10-3-2: A Statutory Right to Substance Abuse Treatment as "Mental Health Care"}

The Court of Appeals was erroneous in holding that substance abuse treatment is not "mental health care" within the meaning of section 11-10-3-2. In addition to section 1110-8-2(a)(4) of the Indiana Code, there are other statutes not examined by the majority in Strawhorn that indicate the legislature's classification of substance abuse treatment as a category of mental health care. Section 12-7-2-130 (a definitional statute under Title 12 of the Indiana Code, "Human Services"), for instance, explicitly states that the term "mental illness" "includes intellectual disability, alcoholism, and addiction to narcotics or dangerous

\footnotetext{
${ }^{153} I d$. (emphasis added).

${ }^{154} \mathrm{Id}$.
} 
drugs." ${ }^{155}$ Further, in section 12-23-5-1, the legislature uses the phrase, "the defendant's mental illness other than substance abuse." $" 156$ By this express exclusion of substance abuse from the "mental illness" discussed in section 12-23$5-1$, the legislature has further demonstrated its understanding of substance abuse as a category of mental illness.

It may be argued by proponents of the statutory holding in Strawhorn that the definition of mental illness in section 12-7-2-130 that expressly includes "alcoholism" and "addiction to narcotics or dangerous drugs" applies only to the provisions within Title 12 and thus only to the state health and welfare agencies governed therein. ${ }^{157}$ Further, proponents of the majority's holding in Strawhorn may argue that because the DOC is governed by a separate title entirely (Title 11), the General Assembly thus intended for a different universe of definitions to apply to the DOC's own statutory framework. However, construing the statutes under Titles 11 and 12 as operationally distinct and severable fails to take into account the multi-faceted approach by which the General Assembly has sought to address the problems of

155 IND. Code ANN. § 12-7-2-130 (West 1992); See also Brief of Appellees in Support of Petition to Transfer at 6, Cohn v. Strawhorn, 721 N.E.2d 342 (1999) (No. 49A02-9903-CV-183), 2000 WL 35439725 (emphasis added).

${ }^{156}$ IND. CODE ANN. § 12-23-5-1(2) (West 1992); See also Brief of Appellees in Support of Petition to Transfer at 6, Cohn v. Strawhorn, 721 N.E.2d 342 (1999) (No. 49A02-9903-CV-183), 2000 WL 35439725 (emphasis added).

${ }^{157}$ IND. CODE ANN. § 12-7-2-130 (West 1992); IND. CODE ANN. § 12-7-1-1 (West 1992) ("Except as otherwise provided, the definitions in this chapter apply throughout this title.") It ought to be noted that although this provision expressly provides that its definitions apply throughout the statutory text of Title 12, it does not require that such definitions be rendered inapplicable as to any other title, much less another title bearing on similar areas of policy. 
recidivism and substance abuse disorders within Indiana's correctional system. One particularly potent illustration of this multi-faceted approach lies in the state Family and Social Service Administration's Recovery Works program. ${ }^{158}$ The Recovery Works program, while administered by the Family and Social Service Administration (which was established under Title 12 of the Indiana Code), ${ }^{159}$ seeks in part to facilitate partnerships between the DOC, county jails, courts, law enforcement, healthcare providers, and other community stakeholders in order to provide substance abuse and mental health treatment programs to individuals within Indiana's criminal justice system. ${ }^{160}$

It is unlikely that the General Assembly would by mere statutory fiction have differing definitions of "mental health care" between Title 11 and Title 12 where the treatment programs administered under both titles provide treatment for mental illness and substance abuse disorders in the same correctional context. The lack of any statutory definition for "mental illness" in the definitions provision of Title 11 further supports the conclusion that the General Assembly's understanding of mental illness includes substance abuse disorders, and that its working conception of mental health care in that context thus includes substance abuse treatment. This is especially likely because the definitional provision of Title 11 has been amended (and significantly so) as recently as 2015, whereas the definition of "mental illness" in Title 12 has not been altered since its initial enactment in 1992. ${ }^{161}$ None of the General Assembly's amendments to the

158 See generally Recovery Works: Indiana's Forensic Treatment Program, IN.GOV, http://www.in.gov/fssa/dmha/2929.htm (last visited Feb. 16, 2017) [https://perma.cc/PK5Y-49CA].

${ }^{159}$ IND. CODE ANN. $§ 12-8-1-1$ (West 1992).

160 Moore, supra note 119, at 6-7.

161 See 2015 Ind. Legis. Serv. P.L. No. 74-2015, sec. 2 (West) (codified as amended at I.C. $§ 11-8-1$ (2015)). 
definitional provision of Title 11 seek to delineate a definition of "mental illness" which deviates from that within Title 12. At first blush, this does not seem to indicate much, but being that the General Assembly has provided for the same kind of substance abuse treatment programming in the same context under both Title 11 and Title 12, it can be presumed that it would have expressly indicated in Title 11 any intent for "mental illness" to encompass different disorders than the disorders treated under Title 12. Thus, as Judge Sullivan argues in his dissent, it is apparent that it is the intent of the General Assembly to consider substance abuse a type of mental illness for purposes of Title 11, and thus to provide for the treatment of such disorders as "mental health care" under section 11-10-3-2.

The majority argues, however, that such an interpretation would result in an absurd application of the statute, namely that section 11-10-3-2 would amount to the recognition of a statutory right to substance abuse treatment for all inmates, "regardless of whether they in fact suffer from substance abuse." 162 At face value, this proposition is indeed absurd. However, looking at the text of section 11-10-3-2, and at the other services to which inmates have a statutory right, it becomes clear that the General Assembly included within the statute an implicit assumption that the statutory right to such services would only vest in inmates who in fact needed them. For instance, section 11-10-3-2 also guarantees inmates a right to "first aid or emergency medical treatment." ${ }^{163}$ Such a right to first aid or emergency care is necessarily predicated on the need for such care, and thus is clearly not granted by the legislature for all inmates, regardless of whether they have any need for it. Mere ambiguity as to the scope and meaning of "mental health care" cannot render the implicit condition of necessity in

${ }^{162}$ Cohn v. Strawhorn, 721 N.E.2d 342, 348-49 (Ind. Ct. App. 1999).

${ }^{163}$ IND. CODE ANN. § 11-10-3-2(c)(2) (West 1993). 
section 11-10-3-2 inapplicable to that particular category of care.

The requirements and practices of the DOC in its administration of such treatment programs further demonstrate an intent that substance abuse treatment and mental health care programs are provided only to inmates who are found to have a need for it. Such gatekeeping criteria as an inmate's score on the Texas Christian University Drug Screen $^{164}$ and the inmate's earliest possible release date ${ }^{165}$ demonstrate the obvious operating assumption that an exercise of the statutory right to substance abuse treatment under 11-10-3-2(c) must necessarily be predicated on an inmate's need for such treatment. The majority's invocation of the indisputably absurd prospect of providing treatment to inmates who do not need it rests on the faulty notion that textual ambiguity regarding the intended scope of a particular category of care somehow prevents the implicit assumption of necessity in section 11-10-3-2 from applying to that category of care.

Thus, the majority's holding in Strawhorn that section 11-10-3-2 does not provide an entitlement to substance abuse treatment was erroneous.

2. Article 1 Section 23: A Right to Substance Abuse Treatment Programs Under the Indiana Constitution's Privileges and Immunities Clause

${ }^{164}$ Email from Sarah Schelle, Research Analyst, Ind. Dep't of Corr., to Nick J. Erickson, J.D. candidate, Robert H. McKinney Sch. of Law (Oct. 21, 2015, 01:06 PM EST) (on file with author); see TEXAS CHRISTIAN UNIVERSITY, DRUG SCREEN V, SCORING \& INTERPRETATION GUIDE (2014) http://ibr.tcu.edu/wp-content/uploads/2014/11/TCUDSV-sg-v.Sept14.pdf [http://perma.cc/Q5QF-DRS3].

165 Programs, supra note 30. 
Article 1 Section 23 of the Indiana Constitution reads, "The General Assembly shall not grant to any citizen, or class of citizens, privileges or immunities, which, upon the same terms, shall not equally belong to all citizens." 166 The test for determining whether a particular action by the General Assembly comports with Section 23 was laid out by the Indiana Supreme Court in Collins v. Day. ${ }^{167}$ In that case, the plaintiff, an agricultural employee, challenged the constitutionality of Indiana's Worker's Compensation Act. ${ }^{168}$ Specifically, the plaintiff challenged the act's exclusion of agricultural workers from its coverage. ${ }^{169}$ The court first concluded that Section 23 of the Indiana Constitution requires an independent analysis from that of the federal Equal Protection Clause. ${ }^{170}$ Following that determination, the majority in Collins sought to delineate the state constitutional standard to be applied in evaluating Section 23 claims. ${ }^{171}$ Relying on statements during the constitutional convention in 1851 given by some of the proponents of Section 23, the Collins court wrote:

From all available indications, we conclude that at the time of the adoption of Section 23 and its ratification as part of the 1851 Indiana Constitution, the principal purpose was to prohibit the state legislature from affirmatively granting any exclusive privilege or immunity involving the state's participation in commercial enterprise. Section 23 does not appear to have been

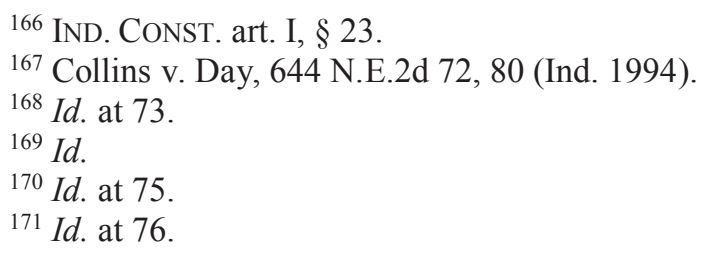


enacted to prevent abridgement of any existing privileges or immunities, nor to assure citizens the equal protection of the laws. ${ }^{172}$

The court went on, however, and reasoned that Section 23's applicability should not be restricted to situations involving the relationship between the state government and private industry:

Longstanding decisions of this Court have expanded the function of Section 23 not only by failing to restrict its application to legislation granting, rather than abridging, privileges or immunities, but also by repeatedly applying Section 23 to matters unconnected with the state's involvement in commercial enterprise, thereby giving preference to the literal language of Section 23 rather than to the intent of its framers. ${ }^{173}$

The court then adopted its present two-pronged test for determining whether an act by the General Assembly has violated Section 23. The first prong requires that the disparate treatment stemming from the legislation must be "reasonably related to inherent characteristics which distinguish the unequally treated classes." "174 The second prong requires that the preferential treatment resulting from the legislation be "uniformly applicable and equally available to all persons similarly situated." 175 The court also held that in proving a piece of legislation fails under the first

\footnotetext{
${ }^{172} \mathrm{Id}$.

${ }^{173} \mathrm{Id}$. at 78 .

${ }^{174} \mathrm{Id}$. at 80 .

${ }^{175} \mathrm{Id}$.
} 
prong, Section 23 plaintiffs must "negative every conceivable basis" for the legislature's classification. ${ }^{176}$ The imposition of such a substantial burden is rooted in a high level of deference for the legislature's discretion in drawing policy lines. ${ }^{177}$ In describing the contours of this deference, the court stated, "Legislative classification becomes a judicial question only where the lines drawn appear arbitrary or manifestly unreasonable ..." 178

In applying this test to the facts in Collins, the court held that the Worker's Compensation Act's exclusion of agricultural workers from coverage did not violate Section $23 .{ }^{179}$ The majority found that under the first prong, there are characteristics inherent to agricultural work which are reasonably related to the Worker's Compensation Act's disparate treatment of agricultural workers, and that the plaintiff had failed to meet the burden of negating every reasonable basis for that legislative distinction. ${ }^{180}$ Among other factors, the court pointed to the traditionally informal nature of agricultural employment and "the peculiar difficulties agricultural employers experience in passing along the additional cost of worker's compensation insurance coverage to the ultimate consumer."181

With respect to the second prong, the Collins court found that the privilege of worker's compensation coverage was uniformly applicable and equally available to all eligible employers. ${ }^{182}$ Thus, the court held that the legislature's exclusion of agricultural workers from worker's

\footnotetext{
${ }^{176} I d$. at 81.

${ }^{177} \mathrm{Id}$. at $79-80$.

${ }^{178} \mathrm{Id}$. at 80 .

${ }^{179} \mathrm{Id}$. at 82.

${ }^{180} \mathrm{Id}$. at 81 .

${ }^{181} \mathrm{Id}$.

${ }^{182} \mathrm{Id}$.
} 
compensation coverage was not a violation of Section 23. ${ }^{183}$ However, it is important to note that the Collins court also acknowledged the possibility of a Section 23 violation resulting from a change in circumstance. ${ }^{184}$ The court wrote, "[w]e do not deny that preferential legislative treatment for a classification which was proper when enacted may cease to satisfy the requirements of Section 23 because of intervening changes in social or economic conditions." 185

In Strawhorn, The plaintiffs argued that the availability of substance abuse treatment programs to DOC inmates housed in state facilities (and the contemporaneous failure to provide such services to DOC inmates housed in county facilities) amounted to an unequal conferral of privilege in violation of Section 23. ${ }^{186}$ The majority in Strawhorn, applying the two-prong test from Collins, found that the disparity in substance abuse treatment across different facilities was not a violation of Section $23 .{ }^{187}$ The court recognized the two classes as 1) DOC inmates housed in county jails, and 2) DOC inmates housed in state prisons. ${ }^{188}$ In applying the first prong of the Collins test, the Strawhorn majority found that the disparate provision of substance abuse programs between county and state facilities was reasonably related to inherent characteristics which distinguished DOC inmates in county jails from DOC inmates in state prisons. ${ }^{189}$ Namely, the court cited the substantially shorter sentences and smaller population of DOC inmates in county jails compared to DOC inmates in

\footnotetext{
${ }^{183} \mathrm{Id}$. at 82.

${ }^{184} \mathrm{Id}$. at 81 .

${ }^{185} \mathrm{Id}$.

${ }^{186}$ Cohn v. Strawhorn, 721 N.E.2d 342, 349 (Ind. Ct. App. 1999).

${ }^{187} \mathrm{Id}$. at 351.

${ }^{188} \mathrm{Id}$.

${ }^{189} \mathrm{Id}$.
} 
state facilities. ${ }^{190}$ Interestingly, the court in Strawhorn fails to conduct any explicit analysis under the second prong in Collins. Instead, the majority moves directly from the first prong to the legislative deference standard, finding that the legislature's disparate provision of substance abuse treatment programs was not deliberate or arbitrary. ${ }^{191}$

The 2014 and 2015 amendments to section 35-38-3-3 substantially alter the distinguishing characteristics relied upon by the Strawhorn majority. In other words, the General Assembly's diversion of Level 6 Felony offenders to county jails constitutes the kind of "intervening change in social or economic conditions" 192 contemplated by the Collins court, and thus warrants a revisiting, on new facts, of the Section 23 analysis in Strawhorn.

First, the incongruence in the availability of substance abuse treatment programs between state and county facilities is no longer reasonably related to any inherent characteristics which distinguish county and state DOC prisoners. Specifically, the redirection of felons into county jails introduces individuals with more severe sentences into county jail populations. This means that the "substantially shorter sentences" 193 relied upon by the Strawhorn majority are no longer an inherent characteristic of county jail inmates. Further, the percentage of DOC inmates serving their sentences in county jails is likely to increase due to the inclusion of Level 6 felons whom were previously housed in state prisons. Thus, the small percentage of DOC inmates in county facilities cited in Strawhorn is likely larger than it was at the time Strawhorn was decided.

The second Collins prong is more easily disposed of in favor of county DOC inmates. That is to say, the privilege of

\footnotetext{
${ }^{190} \mathrm{Id}$.

${ }^{191} \mathrm{Id}$.

${ }^{192}$ Collins v. Day, 644 N.E.2d 72, 81 (Ind. 1994).

${ }^{193}$ Cohn v. Strawhorn, 721 N.E.2d 342, 351 (Ind. Ct. App. 1999).
} 
substance abuse treatment programming is not uniformly applicable or equally available to all similarly situated DOC inmates. This is a fairly self-evident proposition; the spotty availability of treatment programs across even state DOC facilities is anything but uniform or equal. ${ }^{194}$ Despite the DOC's Purposeful Incarceration initiative, which seeks to direct inmates at sentencing to facilities that provide programming relevant to each individual inmate, ${ }^{195}$ it remains that the programs are not themselves provided in a uniformly applicable and equally available way.

Lastly, in affording substantial deference to the General Assembly's discretion in policymaking, it is possible a court may still find that the disparate provision of substance abuse programs across state and county DOC facilities does not violate Section 23. It is unlikely a court will find that the General Assembly's incongruent provision of substance abuse programming across different DOC and county facilities rises to the level of arbitrariness or manifest unreasonableness. This is primarily because the Strawhorn majority's concern for budgetary challenges ${ }^{196}$ remains a valid and compelling concern that is well within the discretion of the legislature. Thus, absent evidence or special circumstances to the contrary, it is unlikely a court will find that the DOC's failure to provide programs equally and adequately in all state and county facilities is arbitrary or manifestly unreasonable. However, because of the substantial shift in social and economic circumstances regarding inmate housing under the recently-amended section 35-38-3-3, the disparate provision of treatment programs across state and county facilities likely now fails the two-pronged Collins test, thus representing a de facto

\footnotetext{
${ }^{194}$ Programs, supra note 30.

195 Purposeful Incarceration, supra note 18.

196 Strawhorn, 721 N.E.2d at 351.
} 
violation of Section 23. Further, the budgetary reforms introduced by the amendments to section 35-38-3-3197 call into question the negative fiscal ramifications feared by the Strawhorn majority, ${ }^{198}$ and undermine any grant of deference that may be afforded the General Assembly regarding the disparate availability of DOC drug treatment programs.

Illustrating the true scope of this change in social and economic conditions, the 2014 amendment authorized $\$ 80$ million in funding, specifically for the expansion and improvement of substance abuse treatment programs in county facilities. ${ }^{199}$ Further, commentary by legislators involved in drafting the bill emphasized a clear legislative prerogative to provide substance abuse treatment to any DOC inmates who need it, and a desire to fundamentally rework the criminal justice system in Indiana. For example, one of the authors of the bill, State Representative Jud McMillin of Brookville, characterized it as "a way to make sure we're keeping people out of jail and keeping families together." ${ }^{200}$ McMillin also characterized the move as a "seismic shift in the way we're addressing criminal justice in the state of Indiana." ${ }^{201}$ Indiana House Speaker Brian Bosma has used stronger language in describing the nature of the new law; he called its passage an "historic moment." ${ }^{202}$ Statements such as these, coupled with the fact that the bill was passed unanimously, indicate an

${ }^{197}$ Guerra, supra note 91.

${ }^{198}$ Strawhorn, 721 N.E.2d at 351.

${ }^{199}$ Kristine Guerra, House Passes $\$ 80$ Million Criminal Justice Bill, The Indianapolis Star (Feb. 23, 2015, 3:29 PM), http://www.indystar.com/story/news/crime/2015/02/23/house-passesmillion-criminal-justice-bill/23895109/ [https://perma.cc/P5F7-VL75].

$$
\begin{aligned}
& { }^{200} \mathrm{Id} . \\
& { }^{201} \mathrm{Id} \text {. } \\
& { }^{202} \mathrm{Id} .
\end{aligned}
$$


unequivocal legislative interest in providing substance abuse treatment programs to all affected DOC inmates, including those housed in county jails. ${ }^{203}$

In sum, failing a direct abrogation of the constitutional holding in Strawhorn, the "historic moment" brought on by the 2014 and 2015 amendments to section 35-38-3-3 warrants a renewed examination of the prospects of the Strawhorn plaintiffs' Section 23 claim. ${ }^{204}$

\section{CONCLUSIONS}

In this Note, I have laid out the role substance abuse and addiction disorders play in driving recidivism, and outlined the various DOC substance abuse treatments programming available to inmates in Indiana's correctional facilities and where they are provided. I highlighted the potential negative ramifications of the 2014 and 2015 amendments to section 35-38-3-3 on county facilities and laid out the various concerns of county administrators. I then argued that recent calls for stiffer drug penalties will not play any significant role in reducing drug abuse and recidivism, and will instead put even greater pressure on county jails. However, the Governor's effort to attack these issues via the Governor's Task Force on Drug Enforcement, Treatment, and Prevention is laudable, and deserves praise.

I have made the case that section 11-10-3-2(c) does in fact grant a statutory right to substance abuse treatment for inmates with substance abuse issues, and that Cohn v.

${ }^{203}$ It ought to be noted that such a unanimous, drastic increase in funding also tends to undermine the Strawhorn majority's inference that generalized notions of "negative fiscal ramifications" necessarily belie any construction of section 11-10-3-2(c) which includes substance abuse treatment within the scope of inmates' statutory right to mental health care. Strawhorn, 721 N.E.2d at 351.

${ }^{204}$ See House Passes $\$ 80$ Million Criminal Justice Bill, supra note 199. 
Strawhorn was erroneously decided on that issue. I argued that the amendments to section 35-38-3-3 represent a substantial shift in social and economic circumstances that may render the Section 23 analysis in Strawhorn erroneous as well, at least with respect to current DOC inmates.

Given Indiana's recent, renewed emphasis on drug policy, overdose prevention, and reducing recidivism in light of a growing heroin crisis, this discussion is likely to continue over the next several years, and a diverse continuum of policy remedies will likely be proposed. At the very least, Indiana's lawmakers ought to resist calls for longer sentences, and should prioritize expanding access to and funding for substance abuse treatment programs inside state and county correctional facilities alike. Indiana's community leaders should continue pursuing collaborative partnerships involving stakeholders across disciplines and industries. The Governor's task force is a step in the right direction, but the private sector (particular healthcare providers and insurers) should take note and increase involvement so as to ensure the further development of best practices and evidence-based reforms. In this way, Indiana may lead the way in providing accessible, effective substance abuse treatment and ultimately reducing the number of Hoosiers incarcerated in and returning to Indiana's correctional facilities. 